PRESSURE SORES 


\section{PRESSURE SORES}

Edited by

J. C. BARBENEL

Bioengineering Unit

University of Strathclyde

Glasgow, Scotland

C. D. FORBES

University Department of Medicine

Royal Infirmary, Glasgow, Scotland

and

G. D. O. LOWE

University Department of Medicine

Royal Infirmary, Glasgow, Scotland 
(C) The contributors 1983

Softcover reprint of the hardcover 1st edition 1983 978-0-333-31889-8

All rights reserved. No part of this publication may be reproduced or transmitted, in any

form or by any means, without permission.

First published 1983 by

The Scientific and Medical Division of

The Macmillan Press Ltd

London and Basingstoke

Companies and representatives throughout the world

ISBN 978-1-349-81353-7 ISBN 978-1-349-81351-3 (eBook)

DOI 10.1007/978-1-349-81351-3

Typeset by

RDL Artset Ltd

Sutton, Surrey 


\section{Contents}

The Session Chairman and the Contributors vii

Preface

Opening Address and Welcome to Participants

M. McInnes

Session 1 Workshop on Wheelchairs

1 Wheelchair services

John Hunter

2 Seating for patients vulnerable to pressure sores

M. W. Ferguson-Pell

3 Special modifications to chairs for posture control

Roy L. Nelham

4 An alternative to the wheelchair

J. C. Griffiths, J. Edwards and A. G. Taylor

Session 1 Discussion

Session 2 Pressure Sores-The Problem

5 Pressure sores

A. A. Barton $\quad 53$

6 Pressure sore prevalence

M. M. Jordan and J. C. Barbenel

7 Measurement of interface pressures

J. C. Barbenel

8 Pressure problems in the elderly

A. N. Exton-Smith 
9 Spinal shock in paraplegia-early skin care

N. Watson

10 Skin care and long-term rehabilitation

N. Watson

11 Young disabled in the community

E. G. Cantrell and J. Dawson

12 The role of the occupational therapist in pressure sore prevention R. Crewe

13 Nursing aspects of pressure sore prevention P. T. Lowthian

14 The problem of pressure sores in multiple sclerosis and severe disability

F. Rigby

Session 5 Devices and Surgical Treatment

15 Aids in prevention and treatment of pressure sores: contoured cushion fabrication using the Shapeable Matrix

S. J. Cousins, K. N. Jones and K. E. Ackerley

16 Movements during sitting and their relationship to pressure sores G. I. Bardsley, F. Bell, R. C. Black and J. C. Barbenel

17 The use of thermography in the prevention of pressure sores R. C. Black and L. D. Reed

18 The surgical treatment of pressure sores William Henry Reid 


\section{The session chairmen and the contributors}

K. E. Ackerley

Superintendent of Technicians

Bioengineering Centre

Department of Mechanical Engineering

University College London

Roehampton Lane

London SW15 5PR

Cairns Aitken, M.D., F.R.C.P.E., F.R.C.Psych.

Rehabilitation Studies Unit

University Department of Orthopaedic Surgery

Princess Margaret Rose Orthopaedic Hospital

Fair Mile Head

Edinburgh EH10 7ED

J. C. Barbenel, B.D.S., M.Sc., Ph.D.

Reader

Bioengineering Unit

University of Strathclyde

Wolfson Centre

106 Rottenrow

Glasgow G4 ONW

G. I. Bardsley, B. Eng., Ph.D.

Research Engineer

Dundee Limb Fitting Centre

Broughty Ferry

Dundee DDS 1AG

A. A. Barton, M.D., B.S., B.Sc.

Head of Pressure Sore Unit

Nunnery Fields Hospital

Canterbury

Kent

F. Bell, B.Sc., Ph.D., C.Eng., M.I.Mech.E.

Senior Research Fellow

Rehabilitation Studies Unit

University Department of Orthopaedic Surgery

Princess Margaret Rose Orthopaedic Hospital

Edinburgh EH70 7ED

R. C. Black, B.Sc., B.A.Sc., P.Eng.

Medical Engineering Section

National Research Council of Canada
Ottawa

Ontario K1A 0R6

Canada

E. G. Cantrell, M.D., F.R.C.P.

Senior Lecturer/Consultant in Rehabilitation and Rheumatology

Southampton General Hospital

Southampton, Hants.

S. J. Cousins, B.A.Sc., M.S.Sc.

Rehabilitation Engineer

Department of Mechanical Engineering

University College London

Roehampton Lane

London SW15 5PR

R. Crewe, M.B.A.O.T., S.R.O.T.

Research Fellow

University of Southampton

Rehabilitation Studies Department

Southampton General Hospital

Tremona Road

Southampton, Hants.

Rosemary Crow, Ph.D., M.A., S.R.N., S.C.M., H.V.

Director

Nursing Practice Research Unit

Northwick Park Hospital and Clinical

Research Centre

Watford Road

Harrow HA1 3DJ

J. Dawson, S.R.N.

Specialist Health Visitor

Care Attendant Co-ordinator

Southampton General Hospital

Southampton, Hants.

J. Edwards, B.Sc., M.Sc., Ph.D.

Professor and Chairman of Department of

Orthopaedic Mechanics

University of Salford

and

Technical Director of Salford

Orthopaedic Appliance Unit

University of Salford 
A. N. Exton-Smith, M.A., M.D., F.R.C.P. Department of Geriatric Medicine

School of Medicine

University College London

St Pancras Hospital

St Pancras Way

London NW1 OPE

M. W. Ferguson-Pell, B.Sc., Ph.D.

Formerly Lecturer

Bioengineering Unit

University of Strathclyde

Wolfson Centre

106 Rottenrow

Glasgow G4 0NW

C. D. Forbes, M.D., F.R.C.P.

Senior Lecturer in Medicine and Honorary Consultant Physician

University Department of Medicine

Royal Infirmary

86 Castle Street

Glasgow G4 OSF

J. C. Griffiths, M.B., Ch.B., F.R.C.S., Ch.M. Consultant Orthopaedic Surgeon

Salford Area Health Authority

and

Medical Director of the Salford Orthopaedic Appliance Unit

University of Salford

D. L. Hamblen, M.R.C.S., L.R.C.P., M.B., B.S., F.R.C.S., Ph.D.

Department of Orthopaedic Surgery

Western Infimary

Glasgow G11 6NT

John Hunter, B.Sc., M.B., Ch.B., M.R.C.P.(U.K.) Consultant Physician in Rehabilitation Medicine

Astley Ainslie Hospital

Edinburgh

and

Part-time Lecturer in Rehabilitation Studies

University of Edinburgh and

Princess Margaret Rose Orthopaedic Hospital

Edinburgh

K. N. Jones

Technician, Bioengineering Centre

Department of Mechanical Engineering

University College London

Roehampton Lane

London SW15 5PR
M. M. Jordan, M.Sc., Ph.D.

Computing Laboratory

National Institute for Medical Research

The Ridgeway

Mill Hill

London NW7 1AA

G. D. O. Lowe, M. B., Ch.B., M.R.C.P.

Lecturer in Medicine and Honorary Senior Registrar

University Department of Medicine

Royal Infirmary

86 Castle Street

Glasgow G4 0SF

P. T. Lowthian, S.R.N.

Nursing Officer

Royal National Orthopaedic Hospital

Brockley Hill

Stanmore

Middx HA7 4LP

M. McInnes

Vice-Chairman, Executive Committee

Int. Year of Disabled People

18 Claremont Cres, Edinburgh, EH7 4QD

Roy L. Nelham, B.Eng., C.Eng., M.I.Mech.E.

Senior Rehabilitation Engineer

Rehabilitation Engineering Unit

Chailey Heritage Hospital

Lewes

Sussex

L. D. Reed, B.Sc., Ph.D.

Head of the Environmental Protection Section

Defense Research Establishment Ottawa

Ottawa

Ontario

Canada

William Henry Reid, F.R.C.S.

Consultant Plastic Surgeon

Canniesburn Hospital

Bearsden

Glasgow G61

F. Rigby

Multiple Sclerosis Society

Maidenhead

Berks

J. C. Robertson, M.B., B.S., M.R.C.P., D.C.H.

Consultant in Rheumatology and Rehabilitation

Salisbury General Infirmary

Firsherton Street

Salisbury

Wilts. SP2 7SX 
A. G. Taylor, M.S.c., C.Eng., M.R.Aes. Scientific Officer

Department of Orthopaedic Mechanics University of Salford
N. Watson, M.B., Ch.B., D.P.H.

Consultant Physician

Spinal Injuries Unit

Lodge Moor Hospital

Sheffield S10 4LH 


\section{Preface}

The contents of this book are based on a symposium held at the Royal College of Physicians and Surgeons of Glasgow. Pressure sores have become a subject of growing interest to clinicians, nurses, therapists and bioengineers, and the editors believed that a symposium which brought together representatives of these disciplines would be both useful and timely.

The papers in this book are of two types. There are reviews which present an evaluation of the current state of knowledge on the identification of patients at special risk of developing sores, on pressure sore prevention in these patients, on the prevalence of sores and on techniques used in investigation and research. There are also research papers of new work in progress. The subject of the symposium was primarily prevention, and the reader will find no details on treatment, other than surgical; this omission reflects the present state of uncertainty and disagreement on the usefulness of the lotions and potions used in the treatment of sores. Some of this disagreement is also apparent in the discussion, in the book, of the usefulness and dangers of massaging the tissue.

The sympsoium was arranged by the Royal College of Physicians and Surgeons of Glasgow, and made possible by the financial assistance of:

Dow Corning Ltd

Tosara Products (UK) Ltd

Armour Pharmaceuticals Co. Ltd

Robert Kellie and Son Ltd

The Multiple Sclerosis Society

Bio Medical Services

Sterling Research Laboratories

Lederle Laboratories
Hawkley and Sons Ltd

Dermalex Co. Ltd

Nottingham Medical Equipment Co.

Price Brothers and Co. Ltd

Seton Group of Companies

Mediscus Products Ltd

3M UK Ltd

The editors gratefully acknowledge the co-operation and assistance of all concerned.

Glasgow, 1982

JCB

$\mathrm{CDF}$

GDOL 